\title{
JUURNAL.RU
}



Батчаева 3.Б. Северо-Кавказская государственная гуманитарно-технологическая академия, Юридический институт Черкесск, Россия

doi: 10.18411/lj-30-04-2017-3-11

idsp 000001:lj-30-04-2017-3-11

\section{Правовые последствия деятельного раскаяния при определении уголовной ответственности и наказания}

При определении уголовной ответственности и назначении наказания законодатель особое внимание уделяет такому обстоятельству как деятельное раскаяние. Правовая интерпретация деятельного раскаяния говорит нам, что активные добровольные действия лица, направленные на предотвращение общественно-опасных последствий, возмещение ущерба и вреда, причиненного совершением преступления, активное способствование раскрытию преступления и т.д. При этом обстоятельством, свидетельствующим, что лицо раскаялось, выступает осознание совершенного им общественно-опасного деяния, причиненного материального и морального вреда. В таком случае можно говорить о роли и значении нравственных началах в уголовном законодательстве при определении и установлении уголовной ответственности и наказания.

Если вернуться к истории уголовного права, можно увидеть что и в Уголовном Кодексе РСФСР деятельное раскаяние рассматривалось и учитывалось как обстоятельство смягчающие наказание при назначении наказания. Так, согласно ст. 38 УК РСФСР 1960г. обстоятельствами, смягчающими наказание признавались:

- предотвращение виновным вредных последствий совершенного преступления;

- добровольное возмещение нанесенного ущерба;

- устранение причиненного вреда; 
- чистосердечное признание;

- явка с повинной;

- способствование раскрытию преступления.

Уголовный закон Российской Федерации уделяет большее значение деятельному раскаянию и рассматривает его как основание освобождения от уголовной ответственности. В частности, в ст.75 Уголовного кодекса РФ законодатель отмечает, что лицо, впервые совершившее преступление небольшой или средней тяжести, может быть освобождено от уголовной ответственности, если после совершения преступления добровольно явилось с повинной, способствовало раскрытию и расследованию этого преступления, возместило ущерб или иным образом загладило вред, причиненный этим преступлением, и вследствие деятельного раскаяния перестало быть общественно опасным. В этой же статье, в части 2 говорится, что лицо, совершившее преступление иной категории, может быть освобожден от уголовной ответственности в том случае, если это предусмотрено конкретными статьями Особенной части Уголовного кодекса. Из-за неопределенности интерпретации данной нормы возникает ряд вопросов. Непонятно в каком значении законодатель указывает на совершение преступления впервые, употребляется оно в отношении лица, который ни разу не привлекался в качестве обвиняемого по делу или же лица, который не имеет судимости в силу освобождения от уголовной ответственности в силу деятельного раскаяния. Получается, что в последнем случае, правила деятельного раскаяния применяются к одному и тому же лицу несколько раз. Можем ли тогда говорить о такой уголовно-правовой цели как исправление лица, совершившего преступление.

Также возникает вопрос относительно того, необходимо ли для освобождения лица от уголовной ответственности в связи с деятельным раскаянием выполнить все перечисленные условия или хотя бы одно из них и какое. При освобождении лица от ответственности должно ли устанавливать его раскаяние в психологическом смысле или нам достаточно того, что он просто испугался, не хочет нести уголовную ответственность или быть судимым. Применительно к этому, О.С. Григорьева говорит, что безусловный характер освобождения от уголовной ответственности лица, ранее совершившего преступления, но освобожденного от ответственности приводит к тому, что положительное посткриминальное поведение виновного может быть связано не с раскаянием, а с избежанием самой уголовной ответственности. 
Судебная практика по этому поводу указывает, что, во-первых, впервые совершенное преступление означает отсутствие у лица судимости; и, во-вторых, собственно наличие или отсутствие самого раскаяния у виновного правоприменитель устанавливает сам. Х.Д. Аликперов по этому поводу отмечает, что раскаяние - это обязательное и полное признание своей вины по всем пунктам, выдвинутого против него обвинения и искреннее его сожаление о содеянном.

Относительно того, какие именно действия необходимо выполнить лицу, виновному в совершении преступления для освобождения его от уголовной ответственности с применением правил деятельного раскаяния, вызывает в научной среде споры между учеными. Необходимо, чтобы присутствовали все перечисленные в ч.1 ст. 75 УК РФ действия, отмечает О.С. Григорьева. С.П. Щерба и А.В. Савкин по этому вопросу определяют, что достаточно выполнения виновным лицом двух или более действий, при этом конкретно не указывает каких именно. Ими же сказано, что для наличия деятельного раскаяния недостаточно одного факта признания вины, а требуется наличие совокупности активных и волевых поступков, объективно подтверждающих раскаяние. Если нет явки с повинной, то нет и деятельного раскаяния, говорит Х.Д. Аликперов, акцентируя при этом большее значение на одном из условий.

Основное значение существования деятельного раскаяния как самостоятельного института уголовного права заключается в недопущении применения норм уголовного преследования, в тех случаях когда это не вызывает необходимости и их применении нецелесообразно.

Интересным и открытым остается вопрос, связанный с выяснением искренности раскаяния лица в своем деянии. Эта ситуация возникает когда правоохранительные органы прекращают уголовное дело в связи с деятельным раскаянием виновного. По мнению Л.В. Лобановой, искреннее раскаяние является обязательным условием освобождения от уголовной ответственности. Это суждение поддерживает и Н.В. Яджин: «чистосердечное раскаяние предполагает обязательно признание лицом совершенного преступного деяния, а также такое поведение виновного, когда он без какого либо притворства осознает, что совершил преступление, откровенно дает об этом показания, и при этом отрицательно оценивает свои действия и готов нести за них ответственность».

Мы больше склоняемся к мнению авторов, которые утверждают, что не может иметь значения наличие либо отсутствие искренности в раскаянии 
виновного лица для освобождения его от уголовной ответственности по основаниям, предусмотренным ст. 75 УК РФ. В этом случае первостепенны и важны такие действия лица, как явка с повинной, способствование раскрытию и расследованию преступления, возмещение причиненного вреда, иное заглаживание вреда, причиненного преступлением.

1. Аликперов Х.Д. Освобождение от уголовной ответственности // ИПК РК Генпрокуратуры РФ. М., 1999. С. 41.

2. Григорьева О.С. Некоторые вопросы совершенствования института освобождения от уголовной ответственности // Актуальные проблемы современного уголовного законодательства (теоретические и практические аспекты): сборник научных трудов. Екатеринбург, 2007.С. 18.

3. Лобанова Л.В. К вопросу о соответствии наименования и содержания статьи 75 УК РФ // Вопросы юридической техники в уголовном и уголовно-процессуальном законодательстве. - Ярославль, 1997. - С. 32.

4. Уголовный кодекс Российской Федерации от 13.06.1996 N 63-Ф3 (ред. от 07.02.2017) // http://www.consultant.ru/document/cons_doc_LAW_10699/2ba2a1c7f4543c624328bd19c1c70 3a7056a3b2f/ (дата обращения: 15.03.2017)

5. Уголовный кодекс РСФСР (утв. ВС РСФСР 27.10.1960) (ред. от 30.07.1996) // http://www.consultant.ru/document/cons_doc_LAW_2950/(дата обращения: 15.03.2017)

6. Щерба С.П., Савкин А.В. Деятельное раскаяние в совершенном преступлении: практическое пособие / под общ. ред. С.П. Щерба. М., 1997. С.11.

7. Яджин Н.В. Явка с повинной и тактика проверки заявлений явившегося. - Тюмень, 1999. C. 18 . 